\title{
RADIO SPECTROSCOPY OF LATE-TYPE VARIABLE STARS
}

\author{
G. M. Rudnitskij \\ Sternberg Astronomical Institute, Moscow State University \\ 13 Universitetskij prospekt, Moscow, 119991, Russia \\ gmr@sai.msu.ru
}

(Received June 12, 2007)

\begin{abstract}
The results of the monitoring of a sample of late-type variable stars (Mira Ceti-type and semiregulars) are reported. Since 1980 a sample of 60 stars has been observed in the maser line of the $\mathrm{H}_{2} \mathrm{O}$ molecule at a wavelength of $1.35 \mathrm{~cm}$. The observations are performed on the RT-22 radio telescope of the Pushchino Radio Astronomy Observatory. Since 1994 optical spectra of some of these stars have also been monitored on the 1.25-meter telescope of the Crimean Laboratory of the Sternberg Astronomical Institute. Variations of the circumstellar $\mathrm{H}_{2} \mathrm{O}$ masers correlate with the visual light curves with a time lag of $0.3-0.4 P$ ( $P$ is the star's period). Flares of the $\mathrm{H} \alpha$ emission noted in $\mathrm{R}$ Leo, U Aur, R Cas, and R LMi were followed 1.5-2 years later by the corresponding flares of the $\mathrm{H}_{2} \mathrm{O}$ masers. These phenomena can be interpreted as a consequence of propagation of a shock wave driven by stellar pulsation. However, radio continuum observations suggest that such shocks (if any) may be rather weak, with a velocity that does not exceed $15-20 \mathrm{~km} / \mathrm{s}$. Alternatively, the shock can be produced by the motion of a low-mass companion (a planet or a brown dwarf) in the inner layers of the circumstellar envelope. The effects of such a companion on the spectrum and light curve of the primary star are discussed. It is shown that a cone shock (similar to that produced in the Earth's atmosphere by the motion of a large meteoritic body) can produce sufficient Balmer line emission without significant accompanying radio continuum. The companion's motion may also account for a significant portion of the primary's light variations without invoking large-amplitude stellar pulsations, which so far have been accepted as the main mechanism of Mira-type variability in red giants.
\end{abstract}

Key words: Stars: AGB and post-AGB; variables: others; masers; radio lines: stars.

PACS number(s): 33.20.Bx, 95.85.Bh, 97.20.Li, 97.30.-b, 97.60.-s, 97.10.Fy

\section{INTRODUCTION}

Long-period variable stars (LPVs) are of great interest, since they represent the final stage in the evolution of solar-type stars. They form one of the most numerous groups among variable stars (several thousand, according to the latest surveys, e.g., NSVS ${ }^{1}$ ). Their periods (or light cycles) $P$ range from $\sim 100^{\mathrm{d}}$ to $\sim 600^{\mathrm{d}}$. At the LPV stage the stars actively lose mass at a rate of $\sim 10^{-7}-10^{-5} M_{\odot} /$ year. The lost material forms extended circumstellar gas-dust envelopes hosting molecular maser radio sources. Several hundred LPVs are known to be sources of maser radio emission in molecular lines $\left(\mathrm{OH}, \mathrm{H}_{2} \mathrm{O}, \mathrm{SiO}\right)$. This emission is highly timevariable, especially in the $6_{16}-5_{23} \mathrm{H}_{2} \mathrm{O}$ rotational line at $\lambda=1.35 \mathrm{~cm}$. To understand the nature of the $\mathrm{H}_{2} \mathrm{O}$ maser variability, our team began the monitoring of a sample of LPVs in the $\mathrm{H}_{2} \mathrm{O}$ line and optical spectrum. Periodic appearance of optical emission lines may suggest the presence of shock waves, which determine the LPV photometric and spectral variations. To connect the LPV variations in the optical and microwave ranges, we have undertaken a long-term multiwavelength monitoring of a sample of stars that includes several tens of Mira-type and semiregular variables. Here I report some results of this monitoring together with a model explaining some particulars of the LPV behaviour.

\section{OBSERVATIONS}

Radio observations in the $\mathrm{H}_{2} \mathrm{O}$ line at $\lambda=1.35 \mathrm{~cm}$ have been performed since 1980 on the 22-meter radio telescope at Pushchino Radio Astronomy Observatory (Astro Space Center of the Lebedev Institute of Physics, Russian Academy of Sciences) [1]. We use a $1.35-\mathrm{cm}$ wavelength receiver with a helium-cooled FET amplifier and a 128-channel filter-bank spectrometer with a resolution of $0.1 \mathrm{~km} / \mathrm{s}$. Since December 2005 we also use for spectral analysis of the signal a 2048-channel autocorrelator with a total bandwidth of $168 \mathrm{~km} / \mathrm{s}$ and velocity resolution of $0.082 \mathrm{~km} / \mathrm{s}$. Intervals between consecutive observing sessions normally do not exceed 1-2 months.

Since 1994, our team has been monitoring a sample of about 30 Miras in the $\mathrm{H} \alpha$ line, see [2] and references therein. For optical spectroscopy, we use a diffraction spectrograph with a maximum resolution of $0.25 \AA /$ pixel.

\footnotetext{
${ }^{1}$ http://skydot.lanl.gov/nsvs/red_variables.php
} 
An echellé spectrograph with a resolving power of 10,000 has been tested. The spectra are recorded with ST-6 and ST-8 Santa Barbara Instruments Group ${ }^{2}$ CCD cameras. This instrumentation is in operation on the 125 -cm telescope at the Crimean Laboratory of the Sternberg Astronomical Institute.

\begin{tabular}{|l|c|c|c|c|}
\hline Name & Type & $P, \mathrm{~d}$ & $\mathrm{H}_{2} \mathrm{O}$ & $\mathrm{H}_{2} \mathrm{O}$ refs \\
\hline \hline R Aql & $\mathrm{M}$ & 284 & + & {$[1]$} \\
RR Aql & $\mathrm{M}$ & 395 & + & {$[6]$} \\
U Aur & $\mathrm{M}$ & 408 & + & \\
RX Boo & $\mathrm{SRb}$ & 340 & + & {$[1]$} \\
R Cnc & $\mathrm{M}$ & 362 & - & \\
R Cas & $\mathrm{M}$ & 430 & + & {$[7]$} \\
T Cas & $\mathrm{M}$ & 445 & - & \\
Y Cas & $\mathrm{M}$ & 413 & + & {$[8]$} \\
o Cet & $\mathrm{M}$ & 332 & - & \\
S CrB & $\mathrm{M}$ & 360 & + & \\
V CrB & $\mathrm{M}$ & 358 & - & \\
R Crt & $\mathrm{SRb}$ & 160 & + & {$[1]$} \\
S Crt & $\mathrm{SRb}$ & 155 & + & {$[1]$} \\
W Cyg & $\mathrm{SRb}$ & 131 & - & \\
$\chi$ Cyg & $\mathrm{M}$ & 408 & - & \\
RY Dra & $\mathrm{SRb}$ & 331 & - & \\
T Dra & $\mathrm{M}$ & 422 & - & \\
RU Her & $\mathrm{M}$ & 485 & - & \\
T Her & $\mathrm{M}$ & 165 & - & \\
U Her & $\mathrm{M}$ & 406 & + & {$[1,9]$} \\
W Hya & $\mathrm{SRa}$ & 361 & + & {$[1,10]$} \\
R Leo & $\mathrm{M}$ & 310 & + & {$[2,11]$} \\
R LMi & $\mathrm{M}$ & 372 & + & \\
RW LMi & $\mathrm{SRa}$ & 640 & - & \\
U Ori & $\mathrm{M}$ & 368 & + & {$[1,12]$} \\
R Peg & $\mathrm{M}$ & 378 & + & \\
S Per & $\mathrm{SRc}$ & 822 & + & {$[13]$} \\
VX Sgr & $\mathrm{SRc}$ & 732 & + & {$[14]$} \\
R Tri & $\mathrm{M}$ & 267 & + & \\
RS Vir & $\mathrm{M}$ & 354 & + & {$[5]$} \\
RT Vir & $\mathrm{SRb}$ & 155 & + & {$[1,15]$} \\
R UMa & $\mathrm{M}$ & 302 & - & \\
\hline
\end{tabular}

+- star observed by us in the $\mathrm{H}_{2} \mathrm{O}$ line;

- no $\mathrm{H}_{2} \mathrm{O}$ data.

Table 1. Long-period variables monitored in 1994-2006 in the $\mathrm{H}_{2} \mathrm{O}$ and $\mathrm{H} \alpha$ emission lines.

In the radio continuum, we have observed a sample of 34 Miras and semiregular variables at $\lambda=6$ and $3 \mathrm{~cm}$ on the Australia Telescope Compact Array in Narrabri [3, 4]. Our sample included mostly southern Miras and semiregulars as well as some well-known objects common with our $\mathrm{H}_{2} \mathrm{O} / \mathrm{H} \alpha$ sample ( $o$ Cet, U Ori, W Hya, R Aql). However, the result was negative: only upper limits on the flux density were determined, from 0.1 to $0.4 \mathrm{mJy}$.

\section{RESULTS}

Figures 1, 2 illustrate the behaviour of the LPVs U Aur and $\mathrm{S} \mathrm{CrB}$ in the visual light, $\mathrm{H} \alpha$ and $\mathrm{H}_{2} \mathrm{O}$ lines. The effect we observe is typical for many stars of the sample. The curve of the integrated $\mathrm{H}_{2} \mathrm{O}$ line flux follows the visual light curve with some phase delay $\Delta \varphi \sim 0.3-0.4 P$, where $P$ is the stellar period. However, maximum visual $-\mathrm{H}_{2} \mathrm{O}$ correlation may not arise promptly, within the same light cycle, but several periods later, as we have found in RS Vir [5].

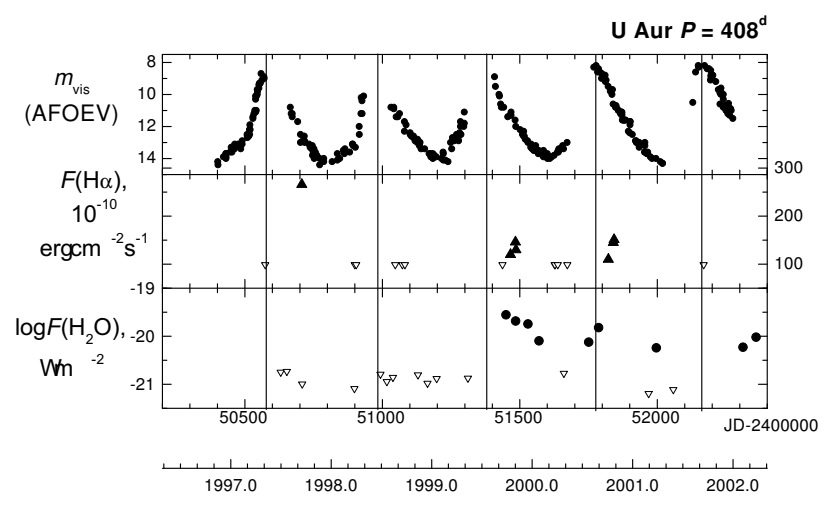

Fig. 1. The data for the Mira variable U Aur. From top to bottom: visual light curve (AFOEV), absolute flux in the $\mathrm{H} \alpha$ emission line, integrated flux in the $\mathrm{H}_{2} \mathrm{O}$ radio line. Open triangles down: upper limits.

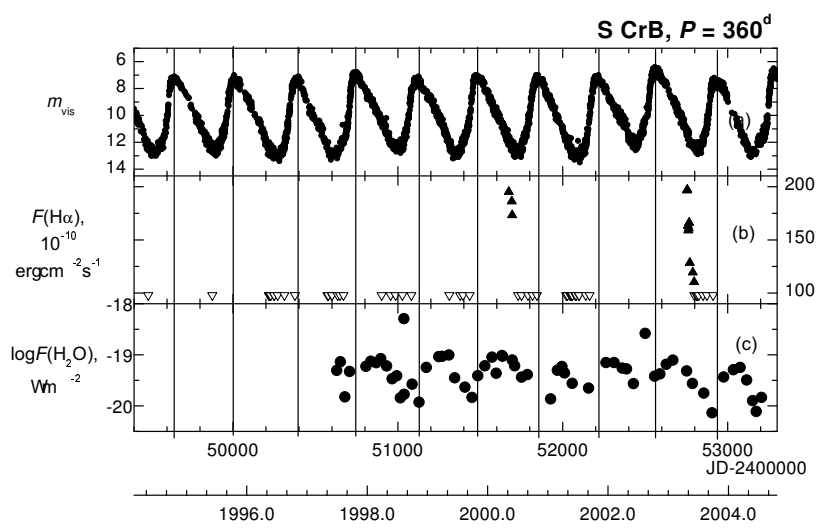

Fig. 2. Same as in Fig. 1, but for the Mira variable S CrB.

We have traced the evolution of the $\mathrm{H} \alpha$ emission in about 30 stars (R Aql, R Leo, R Cas, U Her, $\chi$ Cyg, and others, Table 1). The appearance of the emission is not regular, not all light cycles are accompanied by it. The emission flared at different light phases $\varphi$ of the stars, from minimum to maximum, although phases $\varphi \sim 0.4-0.5$ seem to be preferred. Some stars showed a rather erratic behaviour of the $\mathrm{H} \alpha$ emission. Some others, during our monitoring interval, displayed

${ }^{2}$ http://www.sbig.com/ 
isolated bursts of the $\mathrm{H} \alpha$ emission, followed (about a year and a half later) by a flare of the $\mathrm{H}_{2} \mathrm{O}$ maser radio emission. These stars are R Leo (see [2] for details), R Cas, and U Aur. We have been tracing their $\mathrm{H}_{2} \mathrm{O}$ maser history since early 1980s [1], when they were rather strong $\mathrm{H}_{2} \mathrm{O}$ emitters, but soon faded and remained silent in the $\mathrm{H}_{2} \mathrm{O}$ line until 19971998. Then aparently shock-stimulated flares occurred, see model [16]. Interpreting this in the framework of our model (Section 4) there may be a periastron episode of a planet in a highly eccentric orbit with a period of $P \sim 15$ years.

As for the radio continuum survey, we hoped to find, in addition to the visual $-\mathrm{H}_{2} \mathrm{O}$ and $\mathrm{H} \alpha-\mathrm{H}_{2} \mathrm{O}$ correlations, a radio continuum $-\mathrm{H}_{2} \mathrm{O}$ correlation: the increases in the $\mathrm{H}_{2} \mathrm{O}$ maser flux were supposed to be due to amplification of the varying underlying stellar continuum. The $\mathrm{H} \alpha$-radio continuum correlation could also be of interest. The result was negative [3, 4]. The only star we could detect in the centimeter-wave radio continuum was the symbiotic Mira $\mathrm{R}$ Aqr, which is a well-known radio source [17] (and references therein). The system R Aqr consists of a Mira variable with $P=387^{\mathrm{d}}$ and presumably a white dwarf in an eccentric orbit with $P_{\text {orb }}=44$ years. Our result (integrated flux $S(6 \mathrm{~cm})=17.2 \mathrm{mJy}, S(3 \mathrm{~cm})=15.9 \mathrm{mJy})$ is quite consistent with the MERLIN result [17], $16 \mathrm{mJy}$ at $\lambda=6 \mathrm{~cm}$. This emission is due to a common nebular envelope of the system $\mathrm{R}$ Aqr, its flat spectrum is consistent with that of an optically thin plasma cloud and is not related to the photosphere of the Mira component. The main conclusion of this experiment is that radio continuum from Miras is much weaker than expected for a postshock layer of ionized gas at a shock velocity of $15-20 \mathrm{~km} / \mathrm{s}$ (required to power strong $\mathrm{H} \alpha$ emission). One possible explanation is the presence of a slightly ionized "radio photosphere" [18] that absorbs the radio continuum but lets out the optical emission freely.

\section{DISCUSSION}

It is usually assumed that light variations of Mira-type stars are due to stellar pulsations. The pulsations produce strong shocks that ionize the stellar atmospheric gas thus exciting optical emission lines. However, our observations [3, 4] as well as those of other authors, e. g., [18, 19], have not detected strong radio continuum that would necessarily accompany the optical emission. One explanation is the "radio photosphere" [18].

I propose an alternative hypothesis, which was initially published in my reports $[20,21]$. A similar idea was put forward independently by Berlioz-Arthaud [22]. Details can be found also on the Russian-language Astronet Web page ${ }^{3}$. This hypothesis explains the behaviour of the optical emission lines across a Mira cycle and, probably, the photometric variability.

It is supposed that the optical line emission originates in a local source at the surface of the Mira atmosphere. This source can be a fireball around a nearby companion - a planet or a brown dwarf revolving in an orbit just outside the atmosphere, at a distance of about $1 \mathrm{AU}$ from the stellar center.
Its orbital velocity $\left(\sim 30 \mathrm{~km} / \mathrm{s}\right.$ for a central mass of $\left.\sim 1 M_{\odot}\right)$ is highly supersonic. Estimates [21] show that the conical shock around and behind the companion emits enough $\mathrm{H} \alpha$ quanta to account for the observed line fluxes shown in Figures 1 and 2. Moreover, the total brightness variations of a Mira can be explained to a considerable extent by the "fireball" effect.

Figure 3 shows the location of the companion's orbit with respect to the star and to the sky plane. Figure 4 presents model light curves due to the fireball radiation. At the right the projection of the orbit onto the sky plane is shown together with the assumed star and orbit parameters. The amplitude of the model light curve in the $V$ band can reach $2^{m}$, which may be adequate for "regular" semiregulars (such as the quasi-periodic SRc star W Hya [10]), but is somewhat low for Miras with visual amplitudes $\Delta m>2.5^{m}$.

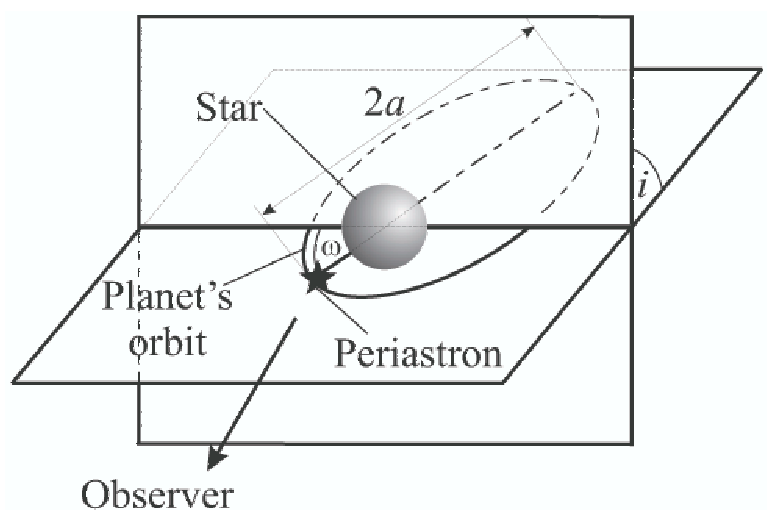

Fig. 3. Parameters of the planetary orbit: $2 a$ is the major axis, $\omega$ is the periastron longitude, $i$ is the angle of inclination to the sky plane.

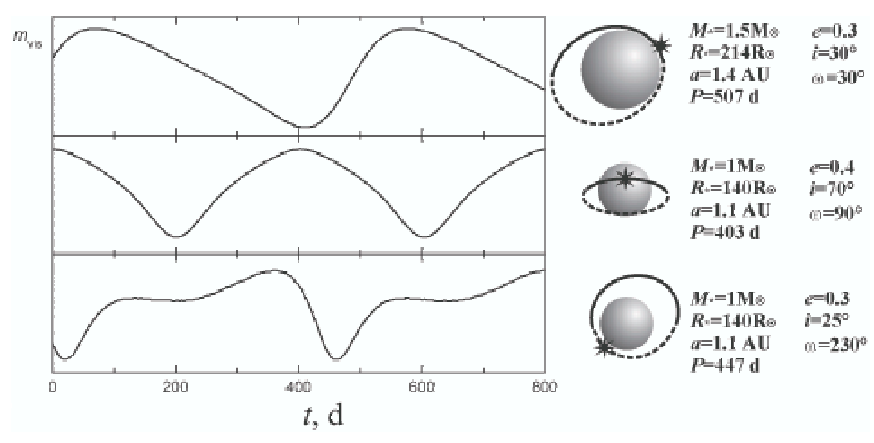

Fig. 4. Model light curves for different parameters of the companion's orbit (see text). Asterisks mark the periastron. Dashed curves: parts of the planetary orbit behind the plane passing thorough the stellar center.

However, this simplified model so far does not take into account secondary effects such as hard radiation of the shock, which reduces opacity around the fireball, thus uncovers deeper atmospheric layers and adds to the brightness variation. Another effect can be tidal excitation of nonradial pulsations by the motion of the companion in the atmosphere. These

${ }^{3}$ http://www.astronet.ru/db/msg/1202883 


\section{G. M. RUDNITSKIJ}

effects are to be considered in forthcoming publications. Finally, the trailing shock from the fireball reaches the masering region in the circumstellar envelope and causes an increase in the $\mathrm{H}_{2} \mathrm{O}$ maser line flux.

The model describes well by purely geometrical effects any shape of the star's light curve. This is achieved by fitting several parameters (stellar mass $M_{*}$, stellar radius $R_{*}$, orbit inclination to the sky plane $i$, periastron longitude $\omega$, semimajor axis $a$, eccentricity $e$ ). Especially interesting light curves are obtained in the case of eccentric orbits - asymmetry, bumps on the ascending/descending branches, and even double maxima (see Fig. 3), as observed, e.g., in the classical Miras R Cen and R Nor.

Irregularities in the brightness variation, which are rather typical in Miras (retarded or advanced maxima as compared to the mean light elements, different heights of the maxima), can be due to a superposition of a random light-curve component. The Miras' light curves are known to consist of two addenda, regular and chaotic [23-25]. The latter component arises from intrinsic (rather erratic) stellar pulsation, whereas the regular component is imposed by the companion's orbital motion. In this hypothesis semiregular variables possess only this chaos; they have no companion in a suitable orbit to maintain the regular Mira-type variation.

Interestingly, our model explains also the periodluminosity dependence for Miras. Many versions of this relationship can be found in the literature, beginning from the classical paper of Clayton \& Feast [26], who gave this dependence in a tabular form $\left(P\right.$ versus $\left.M_{V}\right)$ for Miras in the Large Magellanic Cloud. Newer works usually give this dependence as $M=-m \log P+n$ (where $m$ and $n$ are some constants) and use infrared stellar magnitudes. The advantages of this approach are that $(a)$ amplitudes of Miras' light variations and maximum heights vary from cycle to cycle in the infrared much less than in the visual, $(b)$ in the infrared the effect of interstellar extinction (which is usually difficult to take into account for such distant objects as Miras) is much less. In particular, Knapp et al. [27] derived the period $-K$-band absolute magnitude relationship as

$$
M_{K} \propto-3.39( \pm 0.47) \log P .
$$

The period-luminosity dependence in Miras is usually attributed to their pulsation properties. The "planetary" model of the Mira-type variability discussed in this paper, too, yields the correct value for the slope of the period-luminosity relation. Indeed, the star's luminosity $L \propto R_{*}^{2}$ and its absolute magnitude $M \propto-5 \log R_{*}$. On the other hand, if we accept that the star's period $P$ is the period of revolution of a planet at the outskirts of the stellar atmosphere, then, according to Kepler's third law, $P \propto R_{*}^{3 / 2}$, and

$$
M \propto-3.33 \log P,
$$

in accordance with, e. g., relationship (1). The bolometric correction, mass, and effective temperature of the star affect this relationship rather weakly.

Moreover, the "planetary" hypothesis predicts a very similar value of the "pulsation constant", though in this case no actual pulsation is involved. The period $P$ of revolution of a planet at distance $R_{*}$ from the stellar center (at the outer boundary of its photosphere) depends on the stellar mass $M_{*}$ as

$$
P=2 \pi \sqrt{\frac{R_{*}^{3}}{G M_{*}}} .
$$

The quantity in the radicand is inversely proportional to the mean density of the star $\rho_{*}$. This precisely matches the formula for the pulsation constant:

$$
Q=P\left(M_{*} / M_{\odot}\right)^{1 / 2}\left(R_{*} / R_{\odot}\right)^{-3 / 2},
$$

For $M=1 M_{\odot}$ and $R_{*}=1 \mathrm{AU}$ we find $Q=0.116 \mathrm{~d}$, which corresponds to the main-tone pulsation. This was shown by Berlioz-Arthaud [22].

\section{CONCLUSION}

Our long-term monitoring of a sample of Miras has confirmed the correlation between the stars' visual brightness and integrated $\mathrm{H}_{2} \mathrm{O}$ maser flux. The model for $\mathrm{H}_{2} \mathrm{O}$ maser variability in late-type giants assumes a direct impact of a moderatevelocity shock $\left(v_{\mathrm{sh}} \sim 5-10 \mathrm{~km} / \mathrm{s}\right)$ reaching the masering region in the circumstellar envelope [16]. The delay between the optical and $\mathrm{H}_{2} \mathrm{O}$ maxima depends on the shock travel time and may be as long as a few stellar periods [5]. The shock model is supported by our $\mathrm{H} \alpha$ line monitoring: the appearance of strong Balmer emission is a diagnostic for the early stage of shock propagation in the stellar atmosphere; as the weakened shock reaches the $\mathrm{H}_{2} \mathrm{O}$ masering region at a few stellar radii outside, it results in an appropriate maser flux increase.

However, the model of a spherical shock, driven by the stellar pulsation and embracing the entire stellar surface, may be not valid. In this case the Balmer emission should be accompanied by the emission in the radio continuum of the entire stellar disk that should be observable at centimeter waves. We could not detect the radio continuum even in the stars previously known to be radio continuum sources ( $o$ Cet, R Aql, W Hya $[18,19])$, though the sensitivity was sufficient (typically $0.1-0.3 \mathrm{mJy}$ at the $3 \sigma$ level). The upper levels obtained imply that strong spherical shocks with front velocities $v_{\text {sh }} \geq 15-20 \mathrm{~km} / \mathrm{s}$ do not exist in Miras or they may be invisible at microwaves because they do not propagate above the radius of the "radio photosphere", $r_{\mathrm{ph}} \sim 2 R_{*}$ [18], strongly absorbing the radio emission, but transmitting the optical emission.

An alternative to the pulsation-driven shock is proposed. The Balmer emission comes from a local source-fireball surrounding a nearby companion (brown dwarf or planet) that revolves around an expanded red giant [21]. The fireball is undetectable at microwaves because of its small angular size. The model accounts well for the appearance of the optical emission lines, it also reproduces the variations of the $\mathrm{H}_{2} \mathrm{O}$ maser, the shape of the visual light curves, and the periodluminosity dependence for Miras.

Acknowledgements. This work was supported by the Ministry of Education and Science of the Russian Federation on the RT-22 radio telescope (facility registration number 01-10) and by the Russian Foundation for Basic Research (project code 06-02-16806). This research has made use of the AFOEV database, operated at CDS, France. 
[1] I. I. Berulis, E. E. Lekht, M. I. Pashchenko, G. M. Rudnitskij, Astron. Zh. 60, 310 (1983).

[2] V. F. Esipov, M. I. Pashchenko, G. M. Rudnitskij, S. V. Fomin, Pis'ma Astron. Zh. 25, 775 (1999).

[3] J. M. Chapman, G. M. Rudnitskij, Asymptotic Giant Branch Stars, IAU Symp. 191 Poster Session, \#P4-01 (Montpellier, France, August 28 - September 1, 1998).

[4] G. M. Rudnitskij, J. M. Chapman, Mon. Not. R. Astron. Soc., in press (2007); astro-ph/0703669.

[5] E. E. Lekht, J. E. Mendoza-Torres, G. M. Rudnitskij, A. M. Tolmachev, Astron. Astrophys. 376, 928 (2001).

[6] I. I. Berulis, E. E. Lekht, V. A. Munitsyn, G. M. Rudnitskij, Astron. Zh. 75, 394 (1998).

[7] M. I. Pashchenko, G. M. Rudnitskij, Astron. Zh. 81, 418 (2004).

[8] G. M. Rudnitskij, M. I. Pashchenko, Pis'ma Astron. Zh. 31, 853 (2005).

[9] L. S. Kudashkina, G. M. Rudnitskij, Peremennye Zvezdy 22, 925 (1988).

[10] G. M. Rudnitskij, E. E. Lekht, I. I. Berulis, Pis'ma Astron. Zh. 25, 467 (1999).

[11] G. M. Rudnitskij, in Circumstellar Matter. Proc. 122 Symp. IAU, (Reidel, Dordrecht, 1987), p. 267.

[12] G. M. Rudnitskij, E. E. Lekht, J. E. Mendoza-Torres, M. I. Pashchenko, I. I. Berulis, Astron. Astrophys. Suppl. Ser. 146, 385 (2000).

[13] E. E. Lekht, G. M. Rudnitskij, J. E. Mendoza-Torres,
A. M. Tolmachev, Astron. Astrophys. 437, 127 (2005).

[14] M. I. Pashchenko, G. M. Rudnitskij, Astron. Zh. 76, 363 (1999).

[15] E. E. Lekht, J. E. Mendoza-Torres, M. I. Pashchenko, I. I. Berulis, Astron. Astrophys. 343, 241 (1999).

[16] G. M. Rudnitskij, A. A. Chuprikov, Astron. Zh. 31, 853 (1990).

[17] S. M. Dougherty, M. F. Bode, H. M. Lloyd, R. J. Davis, S. P. Eyres, Mon. Not. R. Astron. Soc. 272, 843 (1995).

[18] M. J. Reid, K. M. Menten, Astrophys. J. 476, 327 (1997).

[19] G. R. Knapp, P. F. Bowers, K. Young, T. G. Phillips, Astrophys. J. 455, 293 (1995).

[20] G. M. Rudnitskij, The Impact of Large-Scale Surveys on Pulsating Star Research. IAU Coll. 176, ASP Conf. Ser. 203, 384 (2000).

[21] G. M. Rudnitskij, Publ. Astron. Soc. Australia 19, 499 (2002).

[22] P. Berlioz-Arthaud, Astron. Astrophys. 397, 943 (2003).

[23] C. A. Whitney, J. Am. Ass. Var. Star Obs. 13, 31 (1984).

[24] I. A. Klyus, Peremennye Zvezdy 22, 697 (1988).

[25] J. K. Cannizzo, D. A. Goodings, J. A. Mattei, Astrophys. J. 357, 235 (1990).

[26] M. L. Clayton, M. W. Feast, Mon. Not. R. Astron. Soc. 146, 411 (1969).

[27] G. R. Knapp, D. Pourbaix, I. Platais, A. Jorissen, Astron. Astrophys. 403, 993 (2003).

\title{
РАДІОСПЕКТРОСКОПІЯ ЗМІННИХ ЗІР ПІЗНІХ КЛАСІВ
}

\author{
Г. М. Рудницький \\ Державний астрономічний інститут імені П. К. Штернберља, \\ Московсъкий державний університет імені М. В. Ломоносова, \\ Університетсъкий просп., 13, 119991, Москва, Росія
}

\begin{abstract}
Повідомлено про результати моніторингу змінних зір пізніх спектральних класів (типу Міри Кита й напівправильних). Починаючи з 1980 року, вибірку 60 зір спостерігають у мазерній лінії молекули $\mathrm{H}_{2} \mathrm{O}$ на хвилі 1.35 см. Спостереження проводять на радіотелескопі РТ-22 Пущинської радіоастрономічної обсерваторії. Від 1994 року оптичні спектри деяких із цих зір спостерігають на 1.25-метровому телескопі Кримської лабораторії Державного астрономічного інституту імені Штернберга. Змінність навколозоряних мазерів $\mathrm{H}_{2} \mathrm{O}$ корелює з візуальними кривими блиску зір із затримкою 0.3-0.4P ( $P$ - період зорі). Услід за спалахами емісії в лінії Н $\alpha$, відзначеними в зорях R Leo, U Aur, R Cas i R LMi, через 1.5-2 роки відбулися відповідні спалахи мазерів $\mathrm{H}_{2} \mathrm{O}$. Ці події можна інтерпретувати як наслідок поширення ударної хвилі, яку викликали пульсації зір. Однак радіоспостереження в неперервному спектрі показують, що такі ударні хвилі (якщо вони існують) можуть бути досить слабкими, зі швидкістю, що не перевищує 15-20 км/с. В іншій інтерпретації ударну хвилю може створювати рух маломасивного супутника (планети або коричневого карлика) у внутрішніх шарах навколозоряної оболонки. Обговорено вплив такого супутника на спектр і криву блиску зорі. Показано, що конічна ударна хвиля (як у випадку руху великого метеоритного тіла в атмосфері Землі) може створювати спостережувану емісію в бальмерівських лініях, яка не супроводжується помітним радіовипромінюванням у неперервному спектрі. Рухом супутника можна також пояснити значну частину змінности блиску зорі, не залучаючи механізм пульсацій великої амплітуди, який дотепер вважали основним для довгоперіодичної змінности типу Міри Кита в червоних гігантах.
\end{abstract}

